\title{
Relationship between Propionate Metabolism and TCA cycle in Rumen Epithelium of Normal, Starved and Alloxan Diabetic Sheep
}

\author{
Katsuo SETO, Keiko OTUKA, Takashi HIGUCHI, Shiro ISHIDA, \\ Michiko TAKESHIMA, Makiko KON and Masazumi KAWAKAMI \\ Biochemical Research Institute, Kanagawa Rehabilitation Center, Atsugi and \\ Department of Physiology, Yokohama Gity University School of Medicine, Yokohama
}

Mizuko YAMAJI and Tsuneyuki TSUDA

Department of Animal Physiology, Faculty of Agriculture, Tohoku University, Sendai

\section{Arthur L. BLAGK}

Department of Physiological Sciences, University of California, Davis

It was reported that there was a relationship between the propionate metabolism and TCA cycle, and that starvation and alloxan treatment influenced the propionate metabolism, and the relationships between the propionate metabolism and glucolysis were changed by the alloxan treatment in the rumen epithelium of sheep. Further study was designed to elucidiate the relationship between the propionate metabolism and TCA cycle, and how this relationship was influenced by the starvation and alloxan treatments. The following results were obtained in a study on influence of citrate or succinate on the ${ }^{14} \mathrm{C}$-propionate metabolism and of propionate on the metabolism of ${ }^{14} \mathrm{C}$-citrate or -succinate in the rumen epithelium of normally fed, starved and alloxan diabetic sheep.

In the rumen epithelium of normally fed and starved sheep, the ${ }^{14} \mathrm{CO}_{2}$ formation from ${ }^{14} \mathrm{C}$-propionate was increased and the transfer of ${ }^{14} \mathrm{C}$ from ${ }^{14} \mathrm{C}$-propionate into glucose, triglyceride and phospholipid was decreased by the addition of citrate or succinate. And also the formation of ${ }^{14} \mathrm{CO}_{2},{ }^{14} \mathrm{C}$-triglyceride and -phospholipid from ${ }^{14} \mathrm{C}$-citrate or -succinate was increased and the transfer of ${ }^{14} \mathrm{C}$ from ${ }^{14} \mathrm{C}$-citrate or -succinate into glucose, ketone bodies and cholesterol was decreased by the propionate addition in the rumen epithelium of normally fed and starved animals.

Furthermore, the citrate effects on the propionate metabolism and the propionate effects on the citrate metabolism were disappeared by the alloxan treatment. But the succinate effects on the propionate metabolism and the propionate effects on the succinate metabolism were observed in the rumen epithelium of alloxan diabetic animals.

As mentioned above, the citrate or succinate showed the various effects on the propionate metabolism and also the propionate had various effects on the metabolism of citrate and succinate, and these relationships between the propionate metabolism and the citrate metabolism were changed by alloxan treatment in the rumen epithelium of sheep.

(See pp. 67〜73)

Vol. 50 No. 1 


\title{
正常, 飢餓打よびアロキサン糖尿ヒッジの第一胃粘膜に おけるプロピオン酸代謝と TCA サイクルとの関倸
}

\author{
神奈川県総合リハビリテーションセンター生化学研究室,

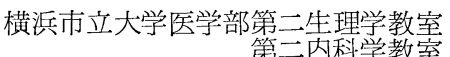 \\ 瀬 戸勝男，大塚 啓子 \\ 樋口隆, 石田孜 郎 \\ 竹 島 三知子, 昆真紀子 \\ 川上 正 澄
}

東北大学農学部家畜生理学教室

\author{
山路 瑞子, 津田恒之 \\ カリホルニヤ大学, デービス, 生理科学科
}

Arthur L. Black

（昭和48年11月 9 日受付）

ヒツジの第一胃粘膜におけるプロピオン酸代謝と TCA サイクルとの関係について検索し, 正常, 飢餓時でプロピオン酸代謝とクエン酸代謝との間に相互作用が存在し, ての相互作用はアロキサン処理 で失われるが，プロピオン酸代謝とコハク酸代謝との間の相互作用は正常，飢餓，アロキサン糖尿時で 存在するととを認めた。

緒 言

ヒツジの第一胃粘膜にわいてマロン酸およびフロロ酶酸の添加がプロピオン酸の消費ならびにそれよりの $\mathrm{CO}_{2}$ の生成を著しく阻害するてとや $\mathrm{CO}_{2}$ の存在のもとでプロピオン酸よりコハク酸が生成するととならび にクエン酸やコハク酸の代謝とプロピオン代謝の間に強い相互作用が存在するととなどの諸事実が既に報告 されている( ${ }^{123}$. 乙れらの諸事実はヒツジの第一胃粘膜においてもプロピオン酸代謝は TGA サイクルと密 接な関係を持っているととを示しているものと思われるが，一方，ヒツシの第一胃粘膜におけるプロピオン 酸代謝が飢餓预よびアロキサン処理の影響を強く受けるとともにプロピオン酸代謝と解糖系とは密接な関係 にあり，しかもそのプロピオン酸代謝と解糖系との関係がアロキサン処理によって著しく変化するてとなど

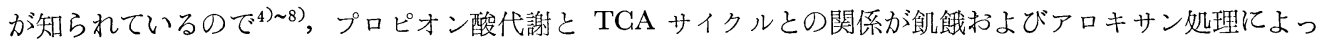
て変化するてとは充分に考えられる.

そてでての点をより明らかとする穾験の一端として正常, 飢餓およびアロキサン糖尿ヒツジの第一胃粘膜 を用いてクエン酸或いはコ八ク酸添加の ${ }^{14} \mathrm{G}$ 一プロピオン酸よりの ${ }^{14} \mathrm{C} の \mathrm{CO}_{2}$, ブドウ糖, ケトン体および 脂質各分画へのとりとみに対する影響ならびにプロピオン酸添加のクエン酸或いはコハク酸代謝に対する影 響について観察を行ない，プロピオン酸代謝とクエン酸代謝との間の相互関係がアロキサン処理で変化する ととを認めたのでそれらの結果について報告する。

\section{方法および材料}

方法および材料はすべて前報てと同様である。即ち動物はメリノ種, 体重 $45 \mathrm{~kg}$ 前後の雌ヒツジを用い乾 第 50 巻 第 1 号 
草600 $\mathrm{g}$ および濃厚飼料 $400 \mathrm{~g}$ を毎日午前 8 時に給与し，乙れを正常飼育群とした。また 7 日間完全に絶食さ

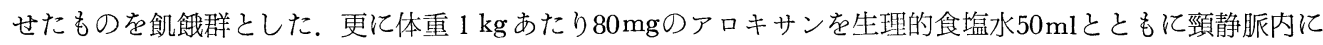
投与したものをアロキサン糖尿群とし投与. 4 日後に実験供した。正常群の血糖値が $60 \mathrm{mg} / \mathrm{dl}$ 前後であるの に対してのアロキサン処理によって屠殺直前の血糖値は $200 \mathrm{mg} / \mathrm{dl}$ 以上になりかなりの上昇を示した。なお ての群における飼育条件は正常飼育群と同様にし，各群とも水道水を自由に摂取させた。

動物は総て午後 3 時に頸動脈よりの放血により屠殺し，すみやかに第一胃粘膜を採取しそその $2 \mathrm{~g}$ を

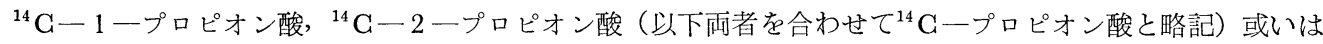
${ }^{14} \mathrm{G}-1,5$-クエン酸（以下 ${ }^{14} \mathrm{C}$ 一クエン酸と略記）， ${ }^{14} \mathrm{C}-1 ， 4$ 一八ク酸（以下 ${ }^{14} \mathrm{G}$ 一 コハク酸と略 記）の $\mathrm{Na}$ 塩 $100 \mu$ moles $(1 \mu \mathrm{Gi})$ を含む Krebs-Ringer 重炭酸緩衝液（pH 7.4） 10m1，とともに気相 $\mathrm{O}_{2}: \mathrm{CO}_{2}=95: 5$ のもと $38^{\circ} \mathrm{C}$ 亿て 3 洔間振盪しながら incubation を行なった。無標識のクエン酸, コハク 酸或いはプロピオン酸を添加する場合もやはりそれら Na 塩 $100 \mu$ moles を含むように調整した。

Incubation 終了後, 前報》に引用した方法により， $\mathrm{CO}_{2}$, ブドウ糖, ケトン体ならびに脂質各分画を分離

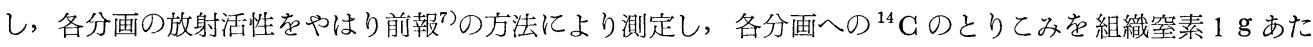
りの $\mu \mathrm{mGi}$ で表現した．との場合の脂質各分画の中の非エステル型脂肪酸（以下 NEFA と略記）分画に は酶酸, プロピオン酸ならび酪酸などは含まれていない.

表に示した総ての值は 5 例の動物について行なった結果の平均 $\mu \mathrm{mGi} \pm$ S.D. であり，ての際その差が $0.1 \mu \mathrm{mCi}$ 以下の場合はたとえ有意の差があってもとりとみの最的な差が少なすぎると考えその差はとりあ げないととにした。

結果

Table 1 および Table 2 亿示したように正常時においてクエン酸或いはコ八ク酸添加は ${ }^{14} \mathrm{C}$ 一プロピオ

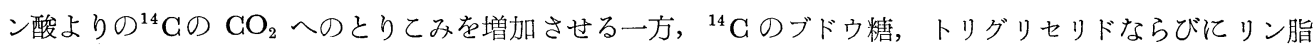

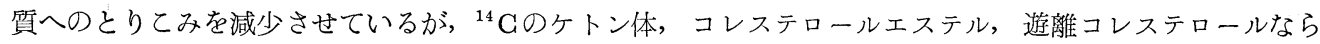

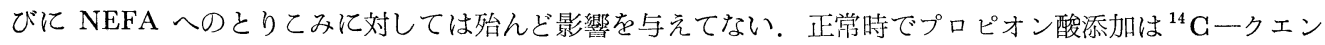

Table 1. Relationship between propionate and citrate metabolism in rumen epithelium of normally fed sheep

\begin{tabular}{|c|c|c|c|c|c|c|c|c|}
\hline \multirow{2}{*}{ Addition } & \multicolumn{8}{|c|}{ Transfer of ${ }^{14} \mathrm{C}$ from ${ }^{14} \mathrm{C}$-propionate or -citrate into } \\
\hline & $\mathrm{CO}_{2}$ & Glucose & $\begin{array}{l}\text { Ketone } \\
\text { bodies }\end{array}$ & $\begin{array}{c}\text { Fraction } \\
\mathrm{A}^{*}\end{array}$ & $\begin{array}{c}\text { Fraction } \\
\mathrm{B}^{*}\end{array}$ & $\begin{array}{c}\text { Fraction } \\
\mathrm{C}^{*}\end{array}$ & $\begin{array}{l}\text { Fraction } \\
\text { D* }\end{array}$ & $\begin{array}{c}\text { Fraction } \\
\text { E* }^{*}\end{array}$ \\
\hline${ }^{14} \mathrm{C}$-1-propionate & $118.5 \pm 4.8$ & $30.1 \pm 1.0$ & $0.0 \pm 0.0$ & $0.0 \pm 0.0$ & $2.5 \pm 0.1$ & $0.0 \pm 0.0$ & $0.0 \pm 0.0$ & $8.7 \pm 0.4$ \\
\hline $\begin{array}{l}{ }^{14} \mathrm{C}-1-\text { propionate } \\
\text { + citrate*** }\end{array}$ & $351.4 \pm 16.1$ & $25.2 \pm 0.9$ & $0.0 \pm 0.0$ & $0.0 \pm 0.0$ & $1.8 \pm 0.0$ & $0.1 \pm 0.0$ & $0.0 \pm 0.0$ & $5.4 \pm 0.2$ \\
\hline${ }^{14} \mathrm{C}-2$-propionate & $24.8 \pm 1.0$ & $64.6 \pm 2.8$ & $0.0 \pm 0.0$ & $0.1 \pm 0.0$ & $4.7 \pm 0.2$ & $0.0 \pm 0.0$ & $0.0 \pm 0.0$ & $22.5 \pm 0.9$ \\
\hline $\begin{array}{l}{ }^{1 \overline{4}} \mathrm{C}-2 \text {-propionate } \\
+ \text { citrate*** }\end{array}$ & $58.7 \pm 1.8$ & $52.0 \pm 2.2$ & $0.0 \pm 0.0$ & $0.1 \pm 0.0$ & $3.4 \pm 0.1$ & $0.1 \pm 0.0$ & $0.0 \pm 0.0$ & $16.9 \pm 0.8$ \\
\hline${ }^{14} \mathrm{C}-1$, 5-citrate & $318.7 \pm 13.6$ & $19.1 \pm 0.8$ & $2.9 \pm 0.1$ & $0.5 \pm 0.0$ & $2.1 \pm 0.1$ & $0.8 \pm 0.0$ & $0.2 \pm 0.0$ & $9.2 \pm 0.3$ \\
\hline $\begin{array}{l}{ }^{14} \mathrm{C}-1,5 \text {-citrate } \\
+ \text { propionate*** }\end{array}$ & $392.5 \pm 15.2$ & $10.7 \pm 0.5$ & $0.5 \pm 0.0$ & $0.1 \pm 0.0$ & $3.0 \pm 0.1$ & $0.1 \pm 0.0$ & $0.3 \pm 0.0$ & $13.9 \pm 0.5$ \\
\hline
\end{tabular}

$2 \mathrm{~g}$ of rumen epithelium were incubated in Krebs-Ringer bicarbonate buffer with ${ }^{14} \mathrm{C}$-propionate or -citrate $(100 \mu$ moles, $1 \mu \mathrm{Gi})$.

*Fraction A, B, G, D and E were composed of cholesterol ester, triglyceride free cholesterol, NEFA and phospholipid, respectively. $* *$ Mean $\mu \mathrm{mGi}$ per $\mathrm{g}$ of tissue $\mathrm{N} \pm \mathrm{S}$. D. in 5 animals. $* * * 100 \mu \mathrm{moles}$ of unlabelled citrate or propionate added into incubation flask. 
Table 2. Relationship between propionate and succinate metabolism in rumen epithelium of normally fed sheep

\begin{tabular}{|c|c|c|c|c|c|c|c|c|}
\hline \multirow{2}{*}{ Addition } & \multicolumn{8}{|c|}{ Transfer of ${ }^{14} \mathrm{C}$ from ${ }^{14} \mathrm{C}$-propionate or -succinate into } \\
\hline & $\mathrm{CO}_{2}$ & Glucose & $\begin{array}{l}\text { Ketone } \\
\text { bodies }\end{array}$ & $\begin{array}{c}\text { Fraction } \\
A^{*}\end{array}$ & $\begin{array}{c}\text { Fraction } \\
\mathrm{B}^{*}\end{array}$ & $\begin{array}{c}\text { Fraction } \\
\mathrm{C}^{*}\end{array}$ & $\begin{array}{c}\text { Fraction } \\
\mathrm{D}^{*}\end{array}$ & $\begin{array}{c}\text { Fraction } \\
\mathrm{E}^{*}\end{array}$ \\
\hline${ }^{14} \mathrm{C}$-1-propionate & $\left|114.6 \pm 5.1^{* *}\right|$ & $29.8 \pm 1.3$ & $0.0 \pm 0.0$ & $0.1 \pm 0.0$ & $2.6 \pm 0.1$ & $0.0 \pm 0.0$ & $0.1 \pm 0.0$ & $8.9 \pm 0.3$ \\
\hline $\begin{array}{l}{ }^{14} \mathrm{C}-1 \text {-propionate } \\
+ \text { succinate*** }\end{array}$ & $382.6 \pm 17.4$ & $23.8 \pm 0.8$ & $0.0 \pm 0.0$ & $0.0 \pm 0.0$ & $1.3 \pm 0.0$ & $0.1 \pm 0.0$ & $0.0 \pm 0.0$ & $4.2 \pm 0.2$ \\
\hline${ }^{14} \mathrm{C}$-2-propionate & $25.7 \pm 1.1$ & $66.0 \pm 3.2$ & $0.0 \pm 0.0$ & $0.0 \pm 0.0$ & $4.8 \pm 0.2$ & $0.0 \pm 0.0$ & $0.0 \pm 0.0$ & $21.7 \pm 0.8$ \\
\hline $\begin{array}{l}14 \mathrm{C} \text {-2-propionate } \\
+ \text { succinate**** }\end{array}$ & $69.7 \pm 2.5$ & $41.3 \pm 1.9$ & $0.0 \pm 0.0$ & $0.0 \pm 0.0$ & $2.2 \pm 0.1$ & $0.0 \pm 0.0$ & $0.0 \pm 0.0$ & $8.3 \pm 0.4$ \\
\hline${ }^{14} \mathrm{C}-1,4$-succinate & $390.1 \pm 16.9$ & $22.3 \pm 0.9$ & $4.3 \pm 0.2$ & $0.5 \pm 0.0$ & $2.3 \pm 0.1$ & $0.9 \pm 0.0$ & $0.3 \pm 0.0$ & $10.2 \pm 0.4$ \\
\hline $\begin{array}{l}{ }^{14} \mathrm{C}-1,4 \text {-succinate } \\
+ \text { propionate**** }\end{array}$ & $504.2 \pm 19.3$ & $16.0 \pm 0.7$ & $0.9 \pm 0.0$ & $0.1 \pm 0.0$ & $5.7 \pm 0.2$ & $0.1 \pm 0.0$ & $0.2 \pm 0.0$ & $18.1 \pm 0.7$ \\
\hline
\end{tabular}

$2 \mathrm{~g}$ of rumen epithelium were incubated in Krebs-Ringer bicarbonate buffer with ${ }^{14} \mathrm{G}$-propionate or -succinate $(100 \mu$ moles, $1 \mu \mathrm{Ci})$.

*Fraction A, B, G, D and E were composed of cholesterol ester, triglyceride, free cholesterol, NEFA and phospholipid respectively. $* *$ Mean $\mu \mathrm{mCi}$ per $\mathrm{g}$ of tissue $\mathrm{N} \pm \mathrm{S}$. D. in 5 animals. $* * * 100 \mu$ moles of unlabelled succinate added into incubation flask.

Table 3. Relationship between propionate and citrate metabolism in rumen epithelium of starved sheep

\begin{tabular}{|c|c|c|c|c|c|c|c|c|}
\hline \multirow{2}{*}{ Addition } & \multicolumn{8}{|c|}{ Transfer of ${ }^{14} \mathrm{C}$ from ${ }^{14} \mathrm{G}$-propionate or -citrate into } \\
\hline & $\mathrm{CO}_{2}$ & Glucose & $\begin{array}{l}\text { Ketone } \\
\text { bodies }\end{array}$ & $\begin{array}{c}\text { Fraction } \\
\mathrm{A}^{*}\end{array}$ & $\begin{array}{c}\text { Fraction } \\
\mathrm{B}^{*}\end{array}$ & $\begin{array}{c}\text { Fraction } \\
\mathrm{C}^{*}\end{array}$ & $\begin{array}{c}\text { Fraction } \\
\mathrm{D}^{*}\end{array}$ & $\begin{array}{c}\text { Fraction } \\
\mathrm{E}^{*}\end{array}$ \\
\hline${ }^{14} \mathrm{C}-1$-propionate & $85.6 \pm 3.3^{* *}$ & $3.1 \pm 0.1$ & $0.0 \pm 0.0$ & $0.0 \pm 0.0$ & $0.2 \pm 0.0$ & $0.0 \pm 0.0$ & $0.0 \pm 0.0$ & $1.2 \pm 0.0$ \\
\hline $\begin{array}{l}{ }^{14} \mathrm{C} \text {-1-propionate } \\
+ \text { citrate } * * *\end{array}$ & $288.1 \pm 12.7$ & $2.4 \pm 0.1$ & $0.0 \pm 0.0$ & $0.0 \pm 0.0$ & $0.0 \pm 0.0$ & $0.0 \pm 0.0$ & $0.0 \pm 0.0$ & $0.5 \pm 0.0$ \\
\hline${ }^{14} \mathrm{C}$-2-propionate & $17.9 \pm 0.8$ & $9.2 \pm 0.4$ & $0.0 \pm 0.0$ & $0.0 \pm 0.0$ & $0.7 \pm 0.0$ & $0.0 \pm 0.0$ & $0.0 \pm 0.0$ & $2.8 \pm 0.1$ \\
\hline $\begin{array}{l}{ }^{14} \mathrm{C}-2 \text {-propionate } \\
+ \text { citrate*** }\end{array}$ & $39.3 \pm 1.4$ & $3.9 \pm 0.2$ & $0.0 \pm 0.0$ & $0.0 \pm 0.0$ & $0.3 \pm 0.0$ & $0.0 \pm 0.0$ & $0.0 \pm 0.0$ & $1.0 \pm 0.0$ \\
\hline${ }^{14} \mathrm{C}-1,5$-citrate & $276.0 \pm 12.3$ & $26.2 \pm 1.1$ & $3.5 \pm 0.1$ & $0.4 \pm 0.0$ & $1.2 \pm 0.0$ & $0.2 \pm 0.0$ & $0.1 \pm 0.0$ & $5.8 \pm 0.2$ \\
\hline $\begin{array}{l}{ }^{14} \mathrm{C}-1,5 \text {-citrate } \\
+ \text { propionate*** }\end{array}$ & $366.8 \pm 13.1$ & $8.3 \pm 0.4$ & $0.2 \pm 0.0$ & $0.0 \pm 0.0$ & $2.3 \pm 0.1$ & $0.0 \pm 0.0$ & $0.0 \pm 0.0$ & $16.6 \pm 0.8$ \\
\hline
\end{tabular}

$2 \mathrm{~g}$ of rumen epithelium were incubated in Krebs-Ringer bicarbonate buffer with ${ }^{14} \mathrm{G}$-propionate or -citrate $(100 \mu$ moles, $1 \mu \mathrm{Ci})$.

*Fraction A, B, C, D and E were composed of cholesterol ester, triglyceride, free cholesterol, NEFA and phospholipid, respectively. **Mean $\mu \mathrm{mCi}$ per $\mathrm{g}$ of tissue $\mathrm{N} \pm \mathrm{S}$.D. in 5 animals. $* * * 100 \mu$ moles of unlabelled citrate or propionate added into incubation flask.

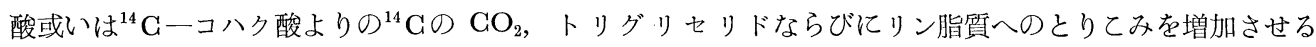
一方, ${ }^{14} \mathrm{C}$ の゙ドウ糖, ケトン体, コレステロールエステルならびに遊離コレステロールへのとりとみを減

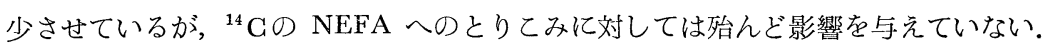

Table 3 および Table 4 亿示したように飢餓時においてクエン酸或いはコハク酸添加は ${ }^{14} \mathrm{G}$ ープロピオ ン酸よりの ${ }^{14} \mathrm{C} の \mathrm{CO}_{2}$ へのとりとみを増加させる一方, ${ }^{14} \mathrm{C}$ のブドウ糖, トリグリセリドならびにリン脂

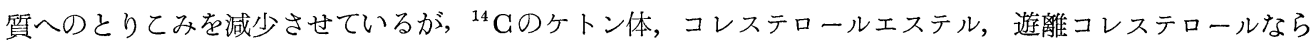
びに NEFA へのとりてみに対しては見るべき影響を与えていない. 飢餓時でのプロピオン酸添加は ${ }^{14} \mathrm{G}-$ 
Table 4. Relationship between propionate and succinate metabolism in rumen epithelium of starved sheep

\begin{tabular}{|c|c|c|c|c|c|c|c|c|}
\hline \multirow{2}{*}{ Addition } & \multicolumn{8}{|c|}{ Transfer of ${ }^{14} \mathrm{C}$ from ${ }^{14} \mathrm{C}$-propionate or -succinate into } \\
\hline & $\mathrm{CO}_{2}$ & Glucose & $\begin{array}{l}\text { Ketone } \\
\text { bodies }\end{array}$ & $\begin{array}{c}\text { Fraction } \\
\text { A* }^{*}\end{array}$ & $\begin{array}{c}\text { Fraction } \\
\mathrm{B}^{*}\end{array}$ & $\begin{array}{c}\text { Fraction } \\
\mathrm{C}^{*}\end{array}$ & $\begin{array}{c}\text { Fraction } \\
D^{*}\end{array}$ & $\begin{array}{c}\text { Fraction } \\
\mathrm{E}^{*}\end{array}$ \\
\hline${ }^{14} \mathrm{C}$-1-propionate & $82.7 \pm 3.6^{* *}$ & $3.0 \pm 0.1$ & $0.0 \pm 0.0$ & $0.0 \pm 0.0$ & $0.2 \pm 0.0$ & $0.0 \pm 0.0$ & $0.0 \pm 0.0$ & $1.1 \pm 0.0$ \\
\hline $\begin{array}{l}{ }^{14} \mathrm{C}-1 \text {-propionate } \\
+ \text { succinate*** }\end{array}$ & $359.1 \pm 16.0$ & $1.5 \pm 0.0$ & $0.0 \pm 0.0$ & $0.1 \pm 0.0$ & $0.0 \pm 0.0$ & $0.0 \pm 0.0$ & $0.0 \pm 0.0$ & $0.5 \pm 0.0$ \\
\hline${ }^{14} \mathrm{C}$-2-propionate & $17.0 \pm 0.9$ & $9.6 \pm 0.2$ & $0.0 \pm 0.0$ & $0.0 \pm 0.0$ & $0.8 \pm 0.0$ & $0.0 \pm 0.1$ & $0.0 \pm 0.0$ & $2.7 \pm 0.1$ \\
\hline $\begin{array}{l}{ }^{14} \mathrm{C} \text {-2-propionate } \\
+ \text { succinate*** }\end{array}$ & $82.6 \pm 3.5$ & $2.6 \pm 0.1$ & $0.0 \pm 0.0$ & $0.0 \pm 0.0$ & $0.1 \pm 0.0$ & $0.0 \pm 0.1$ & $0.0 \pm 0.0$ & $0.6 \pm 0.0$ \\
\hline${ }^{14} \mathrm{C}-1$, 4-succinate & $326.4 \pm 14.8$ & $36.3 \pm 1.2$ & $5.4 \pm 0.2$ & $0.4 \pm 0.0$ & $1.4 \pm 0.0$ & $0.2 \pm 0.0$ & $0.4 \pm 0.0$ & $4.9 \pm 0.2$ \\
\hline $\begin{array}{l}{ }^{14} \mathrm{C}-1, \text { 4-succinate } \\
+ \text { propionate*** }\end{array}$ & $526.0 \pm 20.5$ & $19.7 \pm 0.8$ & $0.7 \pm 0.0$ & $0.1 \pm 0.0$ & $4.0 \pm 0.1$ & $0.0 \pm 0.0$ & $0.3 \pm 0.0$ & $10.6 \pm 0.3$ \\
\hline
\end{tabular}

$2 \mathrm{~g}$ of rumen epithelium were incubated in Krebs-Ringer bicarbonate buffer with ${ }^{14} \mathrm{C}$-propionate or -succinate $(100 \mu$ moles, $1 \mu \mathrm{Ci})$.

*Fraction A, B, C, D and E were composed of cholesterol ester, triglyceride, free cholesterol, NEFA and phospholipid, respectively. **Mean $\mu \mathrm{mGi}$ per $\mathrm{g}$ of tissue $\mathrm{N} \pm \mathrm{S}$.D. in 5 animals. $* * * 100 \mu \mathrm{moles}$ of unlabelled succinate or propionate added into incubation flask.

Table 5. Relationship between propionate and citrate metabolism in rumen epithelium of alloxan diabetic sheep

\begin{tabular}{|c|c|c|c|c|c|c|c|c|}
\hline \multirow{2}{*}{ Addition } & \multicolumn{8}{|c|}{ Transfer of ${ }^{14} \mathrm{C}$ from ${ }^{14} \mathrm{C}$-propionate or -citrate into } \\
\hline & $\mathrm{CO}_{2}$ & Glucose & $\begin{array}{l}\text { Ketone } \\
\text { bodies }\end{array}$ & $\begin{array}{c}\text { Fraction } \\
\mathrm{A}^{*}\end{array}$ & $\begin{array}{c}\text { Fraction } \\
\quad \mathrm{B}^{*} \\
\end{array}$ & $\begin{array}{c}\text { Fraction } \\
\mathrm{C}^{*}\end{array}$ & $\begin{array}{c}\text { Fraction } \\
\mathrm{D}^{*}\end{array}$ & $\begin{array}{c}\text { Fraction } \\
\mathrm{E}^{*}\end{array}$ \\
\hline${ }^{14} \mathrm{C}-1$-propionate & $46.5 \pm 1.9^{* *}$ & $1.1 \pm 0.0$ & $0.0 \pm 0.0$ & $0.0 \pm 0.0$ & $0.2 \pm 0.0$ & $0.0 \pm 0.0$ & $0.0 \pm 0.0$ & $0.3 \pm 0.0$ \\
\hline $\begin{array}{l}{ }^{14} \mathrm{C}-1 \text {-propionate } \\
+ \text { citrate*** }\end{array}$ & $45.2 \pm 2.2$ & $1.3 \pm 0.0$ & $0.0 \pm 0.0$ & $0.0 \pm 0.0$ & $0.3 \pm 0.0$ & $0.0 \pm 0.0$ & $0.0 \pm 0.0$ & $0.4 \pm 0.0$ \\
\hline${ }^{14} \mathrm{C}$-2-propionate & $11.9 \pm 0.5$ & $2.3 \pm 0.1$ & $0.0 \pm 0.0$ & $0.0 \pm 0.0$ & $0.3 \pm 0.0$ & $0.0 \pm 0.0$ & $0.0 \pm 0.0$ & $1.1 \pm 0.0$ \\
\hline $\begin{array}{l}{ }^{14} \mathrm{C} \text {-2-propionate } \\
+ \text { citrate*** }\end{array}$ & $12.5 \pm 0.7$ & $2.2 \pm 0.1$ & $0.0 \pm 0.0$ & $0.0 \pm 0.0$ & $0.4 \pm 0.0$ & $0.0 \pm 0.0$ & $0.0 \pm 0.0$ & $1.2 \pm 0.0$ \\
\hline${ }^{14} \mathrm{C}-1,5$-citrate & $190.9 \pm 8.3$ & $31.9 \pm 1.2$ & $4.0 \pm 0.1$ & $0.6 \pm 0.0$ & $0.7 \pm 0.0$ & $1.0 \pm 0.0$ & $0.2 \pm 0.0$ & $4.2 \pm 0.0$ \\
\hline $\begin{array}{l}{ }^{14} \mathrm{C}-1,5 \text {-citrate } \\
+ \text { propionate } * * *\end{array}$ & $184.7 \pm 9.1$ & $30.5 \pm 1.4$ & $4.2 \pm 0.2$ & $0.5 \pm 0.0$ & $0.8 \pm 0.0$ & $0.9 \pm 0.0$ & $0.2 \pm 0.0$ & $4.0 \pm 0.2$ \\
\hline
\end{tabular}

$2 \mathrm{~g}$ of rumen epithelium were incubated in Krebs-Ringer bicarbonate buffer with ${ }^{14} \mathrm{C}$-propionate or -citrate $(100 \mu$ moles, $1 \mu \mathrm{Ci})$.

*Fraction A, B, G, D and E were composed of cholesterol, triglyceride, free cholesterol, NEFA and phospholipid, respectively. **Mean $\mu \mathrm{mGi}$ per $\mathrm{g}$ of tissue $\mathrm{N} \pm \mathrm{S} . \mathrm{D}$. in 5 animals. $* * * 100 \mu \mathrm{moles}$ of unlabelled citrate or propionate added into incubation flask.

クエン酸或いは ${ }^{14} \mathrm{C}$ 一コハク酸よりの ${ }^{14} \mathrm{C} の \mathrm{CO}_{2}$, トリグリセリドならびにリン脂質へのとりてみを増加さ

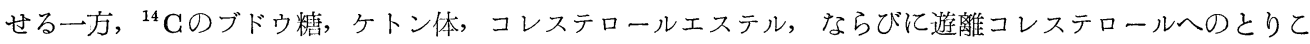
みを減少させているが， ${ }^{14} \mathrm{G} の \mathrm{NEFA}$ へとりてみに対しては見るべき影響を与えていない.

Table 5 に示したようにアロキサン糖尿時においてはクェン酸添加は ${ }^{14} \mathrm{G}$ ープロピオン酸よりの ${ }^{14} \mathrm{C} の$ $\mathrm{CO}_{2}$ ，ブドウ糖，ケトン体ならびに脂質各分画へのとりてみに対して殆んど影響を与えていない．また飢餓 時でのプロピオン酸添加も ${ }^{14} \mathrm{C}$ 一クエン酸よりの ${ }^{14} \mathrm{C} の \mathrm{CO}_{2}$, ブドウ糖, ケトン体ならびに脂質各分画への とりてみに対して見るべき影響を与えていない。 
Table 6. Relationship between propionate and succinate metabolism in rumen epithelium of alloxan diabetic sheep

\begin{tabular}{|c|c|c|c|c|c|c|c|c|}
\hline \multirow{2}{*}{ Addition } & \multicolumn{8}{|c|}{ Transfer of ${ }^{14} \mathrm{C}$ from ${ }^{14} \mathrm{C}$-propionate or -succinate into } \\
\hline & $\mathrm{CO}_{2}$ & Glucose & $\begin{array}{l}\text { Ketone } \\
\text { bodies }\end{array}$ & $\begin{array}{c}\text { Fraction } \\
\mathrm{A}^{*}\end{array}$ & $\begin{array}{c}\text { Fraction } \\
\mathrm{B}^{*}\end{array}$ & $\begin{array}{c}\text { Fraction } \\
\mathrm{C}^{*}\end{array}$ & $\begin{array}{c}\text { Fraction } \\
\mathrm{D}^{*}\end{array}$ & $\begin{array}{c}\text { Fraction } \\
\mathrm{E}^{*}\end{array}$ \\
\hline${ }^{14} \mathrm{C}$-1-propionate & $44.8 \pm 2.2^{* *}$ & $1.2 \pm 0.0$ & $0.0 \pm 0.0$ & $0.0 \pm 0.0$ & $0.3 \pm 0.0$ & $0.1 \pm 0.0$ & $0.0 \pm 0.0$ & $0.4 \pm 0.0$ \\
\hline $\begin{array}{l}{ }^{14} \mathrm{C}-1 \text {-propionate } \\
+ \text { succinate*** }\end{array}$ & $193.0 \pm 7.8$ & $0.6 \pm 0.0$ & $0.1 \pm 0.0$ & $0.1 \pm 0.0$ & $0.0 \pm 0.0$ & $0.0 \pm 0.0$ & $0.0 \pm 0.0$ & $0.0 \pm 0.0$ \\
\hline${ }^{14} \mathrm{C}$-2-propionate & $12.3 \pm 0.4$ & $2.2 \pm 0.1$ & $0.0 \pm 0.0$ & $0.0 \pm 0.0$ & $0.2 \pm 0.0$ & $0.1 \pm 0.0$ & $0.0 \pm 0.0$ & $1.2 \pm 0.1$ \\
\hline $\begin{array}{l}{ }^{14} \mathrm{C} \text {-2-propionate } \\
+ \text { succinate*** }\end{array}$ & $96.9 \pm 4.3$ & $0.2 \pm 0.0$ & $0.1 \pm 0.0$ & $0.0 \pm 0.0$ & $0.0 \pm 0.0$ & $0.0 \pm 0.0$ & $0.1 \pm 0.0$ & $0.5 \pm 0.0$ \\
\hline${ }^{14} \mathrm{C}-1$, 4-succinate & $319.8 \pm 15.1$ & $47.5 \pm 1.9$ & $6.4 \pm 0.3$ & $0.4 \pm 0.0$ & $0.8 \pm 0.0$ & $1.2 \pm 0.0$ & $0.3 \pm 0.0$ & $3.3 \pm 0.1$ \\
\hline $\begin{array}{l}{ }^{14} \mathrm{C}-1,4 \text {-succinate } \\
+ \text { propionate**** }\end{array}$ & $585.2 \pm 23.6$ & $14.3 \pm 0.9$ & $0.5 \pm 0.0$ & $0.0 \pm 0.0$ & $2.5 \pm 0.1$ & $0.4 \pm 0.0$ & $0.4 \pm 0.0$ & $6.5 \pm 0.3$ \\
\hline
\end{tabular}

$2 \mathrm{~g}$ of rumen epithelium were incubated in Krebs-Ringer bicarbonate buffer with ${ }^{14} \mathrm{C}$-propionate or -succinate ( $100 \mu$ moles, $1 \mu \mathrm{Ci}$ ).

*Fraction A, B, G, D and E were composed of cholesterol ester, triglyceride, free cholesterol, NEFA and phospholipid, respectively. ${ }^{* *}$ Mean $\mu \mathrm{mCi}$ per $\mathrm{g}$ of tissue $\mathrm{N} \pm \mathrm{S} . \mathrm{D}$. in 5 animals. $* * * 100 \mu \mathrm{moles}$ of unlabelled succinate or propionate added into incubation flask.

アロキサン糖尿時において，コハク酸添加は ${ }^{14} \mathrm{C}$ 一プロピオン酸よりの ${ }^{14} \mathrm{G} の \mathrm{CO}_{2}$ へのりとみを増加

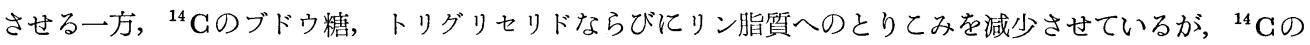
ケトン体, コレステロールェステル, 遊離コレステロールならびに NEFA へのとりとみに対しては見るべ き影響を与えていない. アロキサン糖尿時でもプロピオン酸添加は ${ }^{14} \mathrm{G}$ ーコハク酸よりの ${ }^{14} \mathrm{G} の \mathrm{CO}_{2}, ト リ$

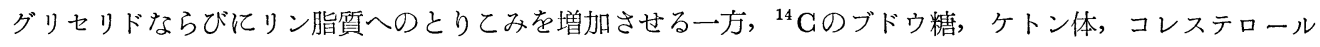

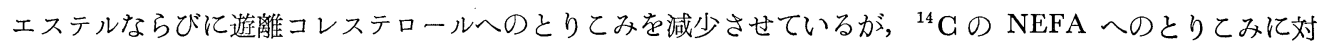
しては殆んど影響を与えていない.

\section{考察}

Pennington \& Sutherland はヒツジの第一胃粘膜において, ${ }^{14} \mathrm{G}$ ープロピオン酸と $\mathrm{CO}_{2}$ との共存の状態 ならびに ${ }^{14} \mathrm{CO}_{2}$ とプロピオン酸の共存の状態のどちらの場合もその ${ }^{14} \mathrm{G}$ が同じ程度にコハク酸にとりこま れるととなどから，ヒツシの第一胃粘膜においてもプロピオン酸は $\mathrm{CO}_{2}$ 固定反応を経てコハク酸に到達し て TGA サイクルに入るものと主張している，てれに対して筆者らは先にプロピオン酸は $\mathrm{CO}_{2}$ 固定反応系 を経て最終的に TCA サイクルによって酸化されるものの, ヒツジの第一胃粘膜ではプロピオン酸の大部 分がコハク酸に到達した後 TCA サイクルに入るとは考えにくいてとを主としてプロピオン酸とコハク酸 の代謝像の相違ならびに酢酸代謝に対する作用の食い違いなどから指摘している ${ }^{3) 9)}$. てれに加うるに ${ }^{14} \mathrm{C} 一$

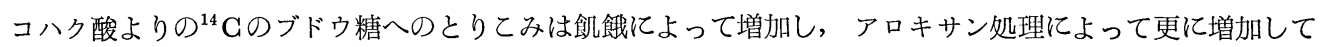

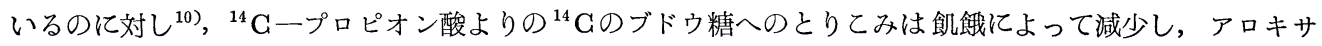
ン処理によって更に減少するなど7)全く逆になっているてとと，更に本報の結果を含めての種々の条件によ

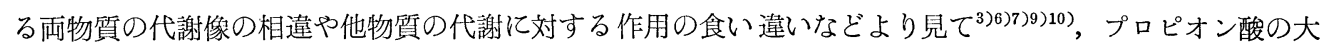
部分がコハク酸に到達すると言う Pennington \& Sutherland の考え方がヒツジの第一胃粘膜にそのままあ てはまるかどうかについての疑問が更に高まったものと考えられる．乙の問題の解決にはヒツジの第一胃粘 膜におけるプロピオン酸の代謝経路そのものについて允分な検索が必要であるととは言う迄もないてとであ り現在，プロピオン酸代謝の中間物質の同定など種々検討中である.

正常, および飢餓ヒツジの第一胃粘膜において焦性ブドウ酸および乳酸はプロピオン酸代謝に対して無影 第 50 巻】第 1 号 
響であるがブドウ糖およびリンエノール焦性ブドウ酸は ${ }^{14} \mathrm{G}$ 一プロピオン酸よりの ${ }^{14} \mathrm{G} の \mathrm{GC}$ ○.のとりとみ

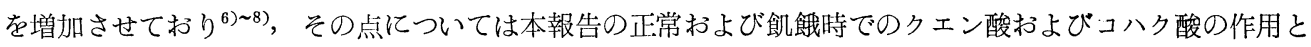
一致しているので, ブドウ糖およびリンェノール焦性ブドウ酸はクェン酸或いはコ八ク酸など何れにしても TGA サイクルに到達してプロピオン酸よりの $\mathrm{CO}_{2}$ 生成系に作用しているものとも考光られる。しかしな

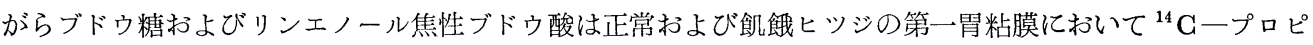

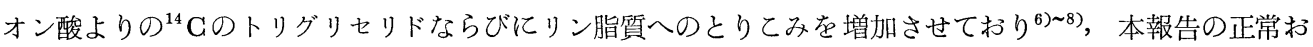

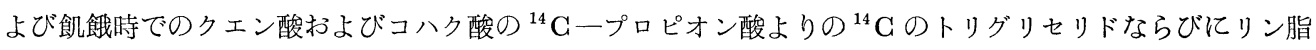
質へのとりてみに対する作用と全く逆になっている，従がって，てれらの諸物質のプロピオン酸代謝に対す る作用を TCA サイクルとの関連において一義的に説明するととは難かしいものと思われる.

一方正常および飢餓ヒツジの第一胃粘膜において認められたブドウ糖およびリンエノール焦性ブドウ酸の

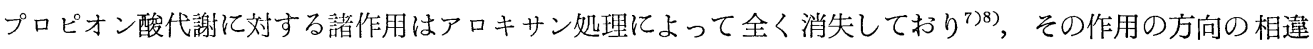
はともかくアロキサン処理による消失という点で本報告のクエン酸のプロピオン酸代謝に対する影響と一致 している.

従がっててれらの物質のプロピオン酸代謝に対する作用にはインシュリンが何等かの形で関与しているも のと思われる，てれに反してヒツジの第一粘膜における ${ }^{14} \mathrm{C}$ 一コ八ク酸よりの ${ }^{14} \mathrm{C} の \mathrm{CO}_{2}$, ブドウ糖, ケト ン体ならびに各脂質分画へのとりとみはアロキサン処理によってかなり変化しているので10), コハク酸より のてれらの物質の生成系にはインシュリンが関与しているものと考えられるが，コハク酸のプロピオン酸代 謝に対する作用はアロキサン䌅尿時でもそのまま存在しているので, コハク酸のプロピオン酸代謝に対する 作用にはインシュリンがあまり関与してないものと思われる。 また一般的に種々の臟器での酢酸, プロピオ ン酸わよび酪酸代謝に対するブドウ糖, リンエノール焦性ブドウ酸, クエン酸或いはコハク酸の作用のアロ キサン処理による変化もほぼ同し傾向にあるので7)10) 16)，乙の関係は臟器の如何にかかわらずまた低級脂 肪酸の如何にかかわらず一般的に成立しているとも考えられる。

プロピオン酸は正常, および飢餓ヒツジの第一粘膜において酢酸よりの $\mathrm{CO}_{2}$ の生成を促進する一方, ブ ドウ糖，ケトン体，コレステロールエステルならびに遊離コレステロールの生成を抑制しており，本報告の クエン酸或いはコ八ク酸代謝に対するプロピオン酸の作用と一致している ${ }^{917)}$. またヒツジの肝スライスで も他の分画の生成に対する作用はともかくプロピオン酸は正常および飢餓時において酶酸および酪酸よりの ケトン体，コレステロールエステルならびに遊離コレステロールの生成を抑制している(5)11)18). てのような ケトン体ならびにコレステロールの生成或いは蓄積の制御はケトーシス或いは高コレステロール血症との関 連も考朰られるのでプロピオン酸のとの抗ケトン的ならびに抗コレステロール的作用の機作については更に

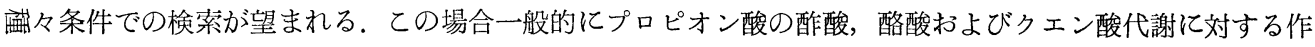
用はアロキサン処理で失われる傾向にあるのに対しコハク酸代謝に対する作用はアロキサン糖尿時にわいて も存在するととはてのプロピオン酸の作用とインシュリンとの関連において興味深い事実と考光られる。

\section{総 括}

ヒツジの第一胃粘膜においてプロピオン酸は TCA サイクルによって代謝されているととならびにプロ ピオン酸代謝が創餓およびアロキサン処理の影響を強く受けるとともにプロピオン酸代謝と解糖系との関係 もアロキサン処理によって変化するてとが知られているので, 更にプロピオン酸代謝と TCA サイクルと の関係ならびそその調節機序をより明らかにする実験の一端として正常, 飢餓およびアロキサン糖尿ヒツジ の第一胃粘膜を用いてプロピオン酸代謝とクエン酸或いはコハク酸代謝との相互関係について検索を行なっ た。

その結果，正常および飢餓ヒツジの第一胃粘膜においてクエン酸或いはコハク酸はプロピオン酸よりの $\mathrm{CO}_{2}$ の生成を促進する一方，ブドウ糖，トリグリセリドならびそリン脂質の生成を抑制する，また正常お 
よび䶿餓時を通じてブロビオン酸はクエン酸或いはコ八ク酸よりの $\mathrm{CO}_{2}$, トリグリセリドならびにりン脂 質の生成垒促進する一方，ブドウ糖，ケトン体ならびにコレステロールの生成を抑制している，てのクエン 酸のプロピオン酸代謝に対する作用ならびにプロピオン酸のクエン酸代謝に対する作用はアロキサン処理に よって消失しているので，このプロピオン酸とクエン酸の相互作用にはインシュリンが関与しているものと 考觉られる。しかしながら正常抢よび飢餓時で認められたコハク酸のプロピオン酸代謝に対する作用ならび にプロピオン酸のコハク酸代謝に対する作用はアロキサン糖尿時でも存在するので，てのプロピオン酸とコ ハク酸との相互作用にはインシュリンは関与してないものと考觉られる.

終わりに脂質分析ならびそ放射活性の測定につきまして種々御指導賜りました東北大学農学部の庄司芳男 博士に深く心より御礼申し上げます。

文献

1) Pennington, R.J. : Biochem. J., $56: 410$ (1954) $\quad$ 2) Pennington, R.J. and T.M. Sutherland: Biochem. J., $63: 618$ (1956) $\quad 3$ ) 瀬戸勝男, 加藤清美, 関口道子, 宮本多栄子, 貴邑冨久子, 川上 和子, 内藤幸子, 大塚啓子 : 生化学, $42: 27,(1970)$ 4) Pennington, R.J. and W.H. Pfander : Biochem. J., 65 : 109 (1957) $\quad$ 5) 安保佳一, 清水勝義, 佐野洋二, 左久: 東北大農生理研究集録, II ：1, (1966). 6) 瀬戸勝男, 加藤清美, 関口道子, 宮本多栄子, 貴邑冨久子, 大塚啓子 : 生化学, $42 ： 19$, (1970). 7) 瀬戸勝男, 根来英雄, 貴邑冨久子, 吉田三知, 柳瀬昌弘, 川上正澄, 山路瑞子, 津田恒之, A.L. Black：：日本内分泌誌, $48: 476,(1972) . \quad 8$ 8) 瀬戸勝男, 樋口 隆, 川上正澄, 竹島三知子, 昆真紀子, 山路瑞子, 洋田恒之, A.L. Black : 日本内分泌誌, $49: 10,(1973)$. 9) 瀬戸 勝男, 本間京子, 関口道子, 宮本多栄子, 貴邑冨久子, 坂西晴三, 大塚啓子: 生化学, $42: 120,(1970)$. 10）瀬戸勝男, 樋口 隆, 川上正澄, 石田孜郎, 竹島三知子, 昆真紀子, 山路瑞子, 津田恒之, A.L. Black : 日本内分泌誌投稿中. 11) 瀬戸勝男, 根来英雄, 吉田三知, 毛利元彦, 真中幹彦, 川上正澄, A.L. Black：日本生理誌，34：746，(1972）。 12）瀬戸勝男, 大塚啓子, 柳瀬昌弘, 佐久間康夫, 川上正澄, A.L. Black：臨床化学, $2 ： 121 ，(1973) . \quad 13 ）$ 瀬戸勝男, 貴邑冨久子, 川上正澄, 山路瑞子, 津田恒之, A.L. Black：日本内分泌誌，49：988，(1973）。 14）瀬戸勝男, 石田孜郎, 竹島三知子, 昆真紀子, 真中幹彦, 川上正澄, A. L. Black : 臨床化学投稿中. 15) 瀬戸勝男, 竹島三知子, 昆真紀子, 佐久間康夫, 川上正澄, A.L. Black : 蹊床化学, $2: 2$, (1973). 瀬戸勝男, 根来英雄, 真中幹彦, 毛利元彦, 佐久間康夫, 川上正澄, A.L. Black : 日本生理誌, 35 : 170, (1973). 17) 瀬戸勝男, 根来英雄, 吉田三知, 川上正澄, 山路瑞子, 津田恒之, A.L. Black : : 日 本内分泌誌， $49: 592 ，(1973)$.

18) Pennington, R.J. : Biochem. J., 65 : 534 (1957) 